\title{
Exploring Livelihood Strategies Pursued by Households in Rongo Sub- County, Migori County, Kenya
}

\author{
Owino Lilian Adhiambo*, Dr. Dennis Mamboleo PhD, Dr. Romborah Simiyu, PhD
}

Department of Geography, Kisii University Kenya

\begin{tabular}{lr}
\hline $\begin{array}{l}\text { DOI: } 10.36348 / \text { jaep.2020.v04i11.001 } \\
\text { *Corresponding author: Owino Lilian Adhiambo }\end{array}$ & $\mid$ Received: $16.10 .2020 \mid$ Accepted: $03.11 .2020 \mid$ Published: 13.11 .2020 \\
Email: lilianaowino11@ gmail.com
\end{tabular}

Abstract

Gold mining is one of the most important economic activities that has the potential of improving livelihoods of households that engage in its extraction. The study was guided by the following objective: to determine livelihood strategies pursued by households in Rongo Sub-County. Descriptive research design and mixed methods were used. Quantitative data was collected using household survey tecnique while Key Informant Interviews, Focused Group Discussions and Case Studies were deployed to collect qualitative data. This study was also supported by Subsistence Livelihood Approach theory. The study was conceptualized on the target population which is 246 which included 223 mining households' heads, 2 ward administrators, 2 area chiefs, 8 secretaries, 8 treasurers and 3 chairmen of gold miners' welfare, two groups from the mining community and two groups from the non-mining community. A household survey technique was used to get the 223 mining household heads. Purposive sampling was used to get 2 ward administrators, 2 chiefs, 8 secretaries, 8 treasurers and 3 chairmen because they were few and the only existing ones. Simple random sampling was used to get two groups from the gold mining community and two groups from the non-mining community members. To ensure the reliability of the study research instruments was 0.67 which was done by test re-test through piloting study. Content validity of research instruments was ensured by two experts from Kisii University, Faculty of Arts and Social Sciences, Department of Geography who helped at scrutinizing them. Anonymity, confidentiality, privacy and informed consent of the respondents was assured. Data was analyzed qualitatively and SPSS Programme was used. The finding of the study revealed that Gold mining generated higher income than other activities, about $61 \%$ of the miners considered gold mining as their primary activity. The study concluded that gold mining had a direct relationship with other livelihood strategies that people of Rongo sub-county engage in and further recommended that it is significant to formulate regulatory measures to ensure that gold mining is practiced within the thresholds of addressing environmental safety. The study helped in giving insights on gold mining as an activity and the bottlenecks that impede it in Rongo sub-county.

Keywords: Livelihood Strategies Households kenya.

Copyright $\odot 2020$ The Author(s): This is an open-access article distributed under the terms of the Creative Commons Attribution 4.0 International License (CC BY-NC 4.0) which permits unrestricted use, distribution, and reproduction in any medium for non-commercial use provided the original author and source are credited.

\section{INTRODUCTION}

When considering mineral wealth in the world, Perks [1] found that there lies varied minerals beneath the Earth's surface that are yet to be discovered. In gold mining, Peiter, Villas and Shinya [2] concur that finding feasible locations bearing rich ore needs skilled and knowledgeable specialists to verify whether or not ore deposits and mineralized masses are feasible for mining to livelihoods technically, economically, socially and politically. Experts, engineers, technicians and support staff work together to make the assessment of feasible locations.

In Asia relatively, Bryceson [3] argues that the reliance of national economies on gold mineral exploration has opened up rural areas where small-scale household miners look for minerals hence excavate the land as a source of career and sustainable livelihood activity. Findings by USAID [4] are that participation in gold mining as a household livelihood activity generally increases with the decreasing scale of operation, particularly in the case of small family operations, where this means of livelihood takes place to supplement other income generating activities or to boost other sources of income. Over the years, gold mining activities in Asia being a primary industry has contributed immensely to the manufacturing sector via the provision of raw materials to secondary industries and in turn leading to development of related industries. This is because the extraction of this precious mineral 
has led to a magnificent impact on the socio-economic lives of households and communities involved directly or indirectly in gold mining sector hence improving their livelihoods [5].

However, Vanessa et al. [6] highlights that many countries in Asia, Africa and Latin America experience serious financial instability with majority of their citizens living below the poverty line. This limits them from being able to exhaustively exploit their available gold mineral resources because of little capital. This is in line with Peiter et al. [2] who also argues that in many developing countries, large part of the population is poor and lives in rural areas, and is dependent on natural capital which includes natural environment that produces mineral resources for its survival. In most rural areas mineral resources endowment has resulted to or holds great potential as drivers of local economic development of households even though unsustainable exploitation of the resources has put at risk to not only the state of environment but also local development and the livelihoods of individuals in such communities. As asserted by Perks [1], many countries that are still developing have a large part of their population living in areas endowed with mineral resources and therefore largely depend on land as their main natural resource and is affected by mining in one way or the other.

In Africa, gold mining provides significant livelihood for rural communities and serves as a means of alleviating poverty [7]. For instance, it has a major impact on employment in most developing countries in Africa. In rural areas of the same developing countries, it provides job opportunities where individuals are engaged in it either directly or indirectly since it involves special and non-special skills hence improving their livelihoods. However, most African countries still languish in poverty despite having several gold resources due to poor exploitation, and overuse of the environmental resources which they exploit for their daily survival. This is because local communities in most African countries do not have enough capital, knowledge, expertise and technology needed to exploit gold on their own [8]. In case of any failure by government to mitigate the above challenges, the locals still find themselves in adverse poverty hence increasing vulnerability in developing countries. The few that engage in gold mining therefore do so in small scale with the main reason of improving their livelihoods. This is as explained by Perks [1], who confirms that the biggest stimulus to participation in gold mining activities is the lure of quick enrichment that comes from its financial and social independence. It is in view that the gold miners get their pay immediately and wages found in gold mining are comparatively higher than employment in construction or agriculture, hence making work in this sector more financially appealing. For this reason it diverts people's attention from other activities despite its known risks making people to abandon other income generating activities. It is in this view that Mitullah, Ogola and Omulo, [9] concluded that most of the small-scale miners are involved in gold extraction because it generates income quickly.

In South Africa, Maxwell [11] asserts that gold mining makes a big contribution in its remote rural areas. This is due to the work involved with the country's civil society which helps in improving governance and charitable organizations hence supporting capacity building especially in sectors like environmental management in polluted areas and public service delivery. This is despite the fact that in most cases, a gold mine may not improve the quality of livelihoods of its surrounding because of misappropriation of funds by the government. Majority of people are therefore involved in small scale gold mining enterprises who make little use of hired labor, or participate in income generating groups on a part-time basis. These people are frequently responsible for food security in their households and have demonstrated competencies in other activities [8]. Gold mining in this country therefore contributes to livelihood enhancement of those involved in it through income generations, increased well-being, and asset acquisitions such as building houses and ownership of land, real estates, cars, among others [11]. Others include reducing vulnerability such as poverty situations and rural-urban migration and any other that may occur. Mining of gold affects livelihood income positively by providing income to miners and other people depending on them either directly or indirectly. This therefore, provides sufficient income to households to take care of their basic needs and household members of their families.

In Ghana, Amankwah and Anim-Sackey, [5] found out that limited employment opportunities or lack of jobs in rural areas, economic hardships, low income earnings in agriculture, and supplementing income generated from other livelihoods are the major driving factors that compel and influence people to combine and use their personal assets to enable them to engage in artisanal gold mining. Since jobs are limited, coupled with low earnings in agriculture and severe economic hardships in the country, many people opt for gold mining despite the risks involved to achieve their basic necessities in life. Mining of gold has positive effects on household livelihoods through income generations to both miners, their dependants and other people who work in related industries and the operations are sources of alternative income generating employment. This has also helped to bridge the gap between the poor and the rich. As supported by Akabzaa and Darimani [12], gold mining in Ghana leads to degradation of farmlands by causing land dereliction and pollution of land and water resources coupled with migrant workers which in turn cause food prices to be high.

This has been the case in some rural areas in Kenya where a majority of the population not only 
resides in rural areas, but also faces poverty and lack adequate opportunities to make a living in the formal sectors of the economy. An example in this case is Rongo Sub-County of Migori County, in South Western part of Kenya. Despite the existence of gold as a mineral resource and its mining taking place in the area, the level of economic development is still low and the environmental consequences are readily visible. The focus of this study therefore is to assess the effects of gold mining on household livelihoods in Rongo SubCounty. This was shown in Table 1. Showing Effects of Gold Mining on Households of Rongo Sub-County 2018-19. Gold mining has had several effects on land and population as indicated in the table.

Table-1

\begin{tabular}{|l|l|l|l|l|l|}
\hline Effects & Occurrence & $\begin{array}{l}\text { Affected Land } \\
\text { Area in Sq. Km }\end{array}$ & $\begin{array}{l}\text { \% of Affected } \\
\text { Area }\end{array}$ & $\begin{array}{l}\text { Affected } \\
\text { Pop. }\end{array}$ & $\begin{array}{l}\text { Percentage of } \\
\text { Affected Pop. }\end{array}$ \\
\hline Land dereliction & Yearly & 77.31 & 36.23 & 38,747 & 31.10 \\
\hline Water pollution & Daily & 67.86 & 31.80 & 37,276 & 29.92 \\
\hline Air pollution & Daily & 76.12 & 35.67 & 35,794 & 28.73 \\
\hline Land pollution & Daily & 77.23 & 36.19 & 37,899 & 30.42 \\
\hline Loss of land fertility & Yearly & 83.65 & 39.20 & 41,587 & 33.38 \\
\hline Death & Occasionally & 45.11 & 21.14 & 21,541 & 17.29 \\
\hline Injuries & Weekly & 79.60 & 37.30 & 42,571 & 34.17 \\
\hline $\begin{array}{l}\text { Other health related hazards } \\
\text { Poor eye sight }\end{array}$ & Occasionally & 63.47 & 29.74 & 6,292 & 29.13 \\
\hline Deafness & Frequently & 58.30 & 27.32 & 34,536 & 27.72 \\
\hline Back aches & Frequently & 72.92 & 34.17 & 43,581 & 34.98 \\
\hline Chest pain & Frequently & 72.13 & 33.80 & 41,936 & 33.66 \\
\hline
\end{tabular}

Source: Migori County Government 2019

Table 1 depicts the effects of gold mining and related hazards on households from the study area. Loss of land fertility, injuries, back- aches and chest pain has affected the largest part of the population. Degradation of environment is also eminent as seen through land dereliction, water pollution, air pollution and land pollution. Other effects include death, poor sights and deafness.

\section{Statement of the Problem}

There are many livelihood activities that households in Rongo sub-county engage in. The activities range from on-farm, post farm and off farm. These activities include farming of maize, sweet potatoes, beans, sugarcane, and gold mining [29]. Besides, there are other post farm activities like processing and value addition like milling of maize, transportation and trading in farm products. However, little is known about the relative importance of the various livelihood activities to households, how they impact on each other and the implication of these impacts on the sustainability of household livelihoods in Rongo sub-county.

Gold mining as asserted by Otuki [13] is practiced by many families in Rongo Sub-County as one of the many livelihood strategies. This is done despite known risks involved like deaths when the mines collapse, injuries, land dereliction, loss of land fertility, pollution and the use of heavy metals like mercury which affects human health adversely by contributing to illness related to the respiratory tract. However, the question as to what drives the population to choose gold mining as the best alternative source of livelihood despite the known risks is not addressed.
From table 1 it is evident that the effect of gold mining in Rongo Sub-County has been rampant and hazardous. This has even caused some accidental deaths, injuries and health related challenges. This therefore made the researcher to fill the gap by examining the relative contribution of gold mining to household livelihoods in Rongo Sub-County and how participation in gold mining affected the sustainability of household livelihoods.

\section{Livelihood Strategies Pursued By Households}

There are many livelihood strategies practiced by different households in the world. According to Lahiri [11], the main strategies include fishing, mining and farming. These activities provide a vital source of food, employment, recreation, trade and economic wellbeing of people engaged in them and form the most important livelihood option for the inhabitants. As argued by Mathis [14], globally most villages are mainly comprised of farmers, fishermen, miners, shop assistants, teachers, health care workers, and other service- related professionals.

Small-scale gold mining as stipulated by Maxwell [10], provides direct income to about 13 million workers and their families worldwide. This is because people are employed to carry out various activities like digging, crushing, milling, hauling of the ore and carrying the grinded ore to be sieved or washed and pumping of water. Therefore, various household livelihoods play a pivotal role in lessening poverty in many rural areas of the developing countries since when people are employed in these livelihood strategies, they get income that helps in improving their living standards together with those who depend on them [1]. Rural areas are the economic backbone of 
most developing countries because of the many economic activities that take place. Depending on a country's level of advancement in the economic sphere, they contribute to overall economic growth by creating jobs, a condusive environment of performing those jobs, supplying adequate manpower and labor, food, and raw materials to other growing related sectors of the economy; and helping to generate foreign exchange for the country.

Despite these significant contributions, however, Owusu-Korateng [15] argues that rural areas are the most marginalized and struck by poverty. They are characterized by poverty, food insecurity, unemployment, inequality, lack of important socioeconomic services and availability of unskilled labor since in most cases, those with skilled labor and adequate technology migrate to towns in search of white color jobs. The livelihood strategies found in rural areas are also influenced by their vulnerabilities such as climate, population numbers, political change and influence, war, terms of trade, food production and social differentiation. There are also liabilities like illness, handicaps, ignorance, fear and individual depression linked to the context of structural poverty, ecological stress and political neglect and their seasonal variations.

Many households engage in investing in various production systems as a strategic choice for their livelihoods in order to meet their basic needs. These livelihood strategies as found out by Ocansey [16] are categorized on the basis of farm like livestock and crop production, off-farm like wage employment in other farms and businesses of farm produce, and nonfarm which are usually nonagricultural income sources such as wage employment, self employment, property income, and remittances. According to Bryceson [3], access to means of livelihood and resources like land, forests, water, fisheries, pastures, minerals, among others is essential for sustainable poverty reduction. Therefore, throughout the world, livelihoods of people without access to the limited natural resources are vulnerable because they highly depend on means of living to obtain food and meet other basic needs. In addition, it is a stimulus for trade and subsidiary business development around mine sites just as is evidenced in industrial or larger-scale gold mining operations. Participation in these activities also affects gold mining in one way or the other. Findings by USAID [4] are that participation in different livelihood activities generally increases with the decreasing scale of the operation, particularly in the case of small- scale family operations, where the means of livelihood takes place to supplement other income generating activities. So many people got job opportunities including those that were not related to gold mining.

In Asia, the major livelihoods found in the Pathen valley are majorly centered on farming and include shifting cultivation of rice and other crops, livestock husbandry, gold mining and the collection of non- timber forest products as subsistence livelihood activities [7]. The livelihood strategies of peasants in China are dynamic and factors affecting households' choices of livelihood strategies include time constraints and skills, household size and composition, rainfall/drought, access to family support, social and cultural conditions, and external incentives economic and environmental conditions. For example, when environmental background, livelihood assets, policies, and systems undergo drastic changes, households tend to transform their livelihood strategies to adapt to new environmental changes. In general, diversification of livelihood strategies and assets play a dominant role in the transformation of rural livelihoods. For example, natural assets, represented by land, are the main constraint for the majority of impoverished rural households while in areas with rapid urbanization, human assets thrust households to turn from agricultural operation to nonagricultural employment.

In embracing different livelihood strategies by households, Bryceson [3] says, fertile paddy fields of the Pathen Valley have been reduced to wasteland by open-cast mining areas due to the mounds of soil left all over after gold mining. This has initiated a change in the way people meet their livelihoods and altered the relationship of peasant farmers and gold mining operators. They therefore have to look for other ways of meeting their livelihoods by being connected to the global market in order to be able to earn additional cash on top of what they get in gold mining to improve their livelihoods. This has led to several adjustments in their livelihood strategies. For example, Lahiri [11] argues that Rural settlements in the Pathen valley have changed into informal gold mining communities, where they are exposed to landscape transformation, livelihood adjustment and exploitation by the global commodity market.

Most African countries still languish in poverty despite having several natural resources due to poor exploitation and overuse of the environmental resources they are able to exploit for their daily survival Vanessa et al. [6]. This is because local communities in most African countries do not have enough capital, knowledge, expertise and technology needed to exploit the resources on their own. They however highly depend on their governments for outsourcing of revenues from other well- developed countries, companies, NGOs or well wishers to extract their resources that appeare to be limitless [8]. This makes most of these countries to be vulnerable to poverty due to natural resource depletion and population pressures.

According to Hinton et al. [18], most governments of developing countries in Africa have a weak rule of law that governs them because of corrupt officials. This in most cases leads to the emergence of powerful groups aiming to gain control over the 
available resources, hence creation of legal and institutional frameworks that allow for unequal distribution of the revenues gained from exploitation of the resources. Maxwell [10] adds that in most developing countries in Africa, most resources at the grassroots community level are still perceived as "free" and "without limit," allowing these corrupt officials to exploit them at will. This is because there is ignorance of most community members and lack of public awareness of the potential scarcity of the resources involved. This partly results from this lack of proper knowledge or awareness, and hence lack of pressure to exploit them. In most cases therefore, resources are being liquidated for immediate economic gain rather than being managed sustainably by members. Households in most developing countries as Dreschler [8] contends are significantly influenced by social and cultural assets in choosing livelihood strategies. Overally, among cultural assets, a household's understanding of knowledge on livelihood strategies is an important factor that restrains other households for example from becoming nonagricultural or part-time agricultural households. Therefore, to ensure the dynamic choices of livelihood strategies, it is advisable to effectively improve cultural assets among households, especially their understanding of means of income. In addition, a livelihood strategy should be promoted that centers on maintaining the well being of households.

In South Africa, gold mining contributes to sustainable development of the surrounding household community and its members by supporting enterprises like jewelry, agriculture, bee keeping and other small business enterprises [18]. Majority of people are therefore involved in small scale enterprises that make little use of hired labor, or participate in income generating groups on a part-time basis.

In rural South Africa, households obtain income and livelihoods from various sources which include income from wages, salaries and commissions; income from own businesses; income from sales of farm produce and services, income from rents and interest; and from remittances, pensions, and grants. These are categorized into three which include on farm, non-farm, and off farm. These result into wage activities which include employment in non-farm salaried activities or employment on farms.

Non-wage activities, on sales of farm produce and services, and rents and interests. These people are frequently responsible for food security and have demonstrated competencies in other activities. For example, in Kwa Zulu Natal, brickmaking provides a means to add value to gold mines especially women who work in the mines [8]. This is also observed by Maxwell [10] who adds that gold mining has affected livelihood of Kwa Zulu both positively and negatively by for example, providing workers with high incomes and other people such as taxi drivers, traders, and food vendors/water sellers who indirectly depend on it for livelihood income by providing their services.

It also has adverse effects on livelihoods of household income through destruction of farm lands through land dereliction, mass wasting and pollution. This has caused some farmers, especially small-scale farm holders, to lose their livelihood and household income which has in turn rendered some to extreme poverty. There are several activities that as Dreschler [8] explains, people are employed to carry out various activities like digging, crushing, milling, hauling of the ore and carrying the grinded ore to be to be sieved or washed. Therefore, mining and especially gold mining plays an important role in alleviating poverty in many rural areas of the developing world since when people are employed in the mines they get income that helps in improving their living standards [1]. This means that the revenue generated by mining contributes more directly to the well-being of households that are involved in it.

In Cameroon, Cerutti, Nasi and Tacconi [19] argue that most miners have increased their farm sizes and businesses with income earned from gold mining. Women who participate in mining practice farming around mining camps and grow a variety of local vegetables, maize, cassava and cocoyam primarily for consumption. Produce from these farms are also sold in most cases for those who live around the mines to earn more income. Those who sell them are able to get extra earnings and in turn improve their living standards. In Mali, the Sadiola Gold Mining Project provides technical assistance to artisanal gold miners and support alternative revenue generating activities such as agriculture, jewelry production, pottery, bee keeping and fabrication of dyes and soaps [20]. Of all these activities, Pottery has emerged as one of the leading activities resulting from gold mining in Zimbabwe. This is because of gold miners travelling several kilometers inside the forest and being able to access clay. These gold miners therefore need to carry their tools, goods and personal belongings to the mines so they make use of the services of porters [21].

In Tanzania, since the inception of large-scale gold mining in Geita District, there have been a lot of complaints raised from the adjacent communities regarding the minimal socio-economic benefits accrued by the local community [22]. In as much as the mining sector acknowledges to have done a lot to improve the livelihoods of the households of the local people around the mine and beyond, communities also continue to complain on the loss of livelihoods and unmet promises. This is because promises made by the mining company encouraged communities around the mining areas that efforts would be made to compensate the disrupted livelihood assets of the surrounding communities and to support them in health and 
education facilities, employment opportunities, water supply projects, encouragement of local business through spill over and multiplier effects, and improvements of infrastructures. This however, according to Perks [1] is yet to be met since people living in the area languish in poverty.

In Migori, many gold miners have been trapped inside mining tunnels and others buried by falling heaps of soil in mining sites. In addition, some have suffocated from fumes emitted from generators that they use to light up the tunnels, and to pump water out of the tunnels which are both vertical and horizontal. Despite this, Mitullah et al. [9] argues that farmers shift their attention from agricultural activities to gold mining due to lower income generation in agriculture in rural areas and unpredictable weather changes which cause reduction in food production in Migori County. For example, in Nyasoti village mining site in Rongo, a quantitative household survey by KNBS [23] showed that gold mining although practiced alongside agriculture is the primary income-generating activity in the area and that $78 \%$ of miners surveyed did not wish to abandon their activity despite the area being fertile and agriculturally productive.

\section{RESEARCH METHODOLOGY}

This research employed descriptive research design and mixed methods as described by [24]. Quantitative data was collected using a household survey technique while key informant interviews (KII), Focused Group Discussions (FGDs) and Case Studies were used to collect qualitative data [25]. The target population was 246. Household survey technique targeted 223 mining household heads as described by [26]. Key informant interviews targeted the welfare groups that consisted of 3 chairmen, 8 secretaries and 8 treasurers; 2 chiefs and 2 ward administrators. FGDs targeted 2 groups of the gold miners and 2 groups of community members who were not necessarily gold miners. Case studies targeted four groups of household heads from household survey technique. This study adopted purposive and random sampling techniques. Purposive sampling was adopted in selecting the 3 chairmen, 8 treasurers and 8 secretaries of the welfare and the 2 chiefs and 2 ward administrators of the area, which was 100 percent. These respondents were purposively sampled due the work of Kothari [27] because they were few and the only existing ones.

By means of simple random sampling, we assume that all members of the population have similar characteristics and so have the same chance of being selected [26]. Therefore, this study also used simple random sampling technique to choose groups for focused discussions and case studies. A household survey technique was used to get 223 mining household heads. The study used two data collection methods which were questionnaires and semi-structured interviews.
The researcher ensured the validity of the research instruments was done by giving the instruments to two experts in the department of geography in the Faculty Arts and Social Sciences of Kisii University to scrutinize and validate them. To ensure the reliability of the study the researcher conducted a test re-test which was done through piloting study. The correlation coefficient of test re-test results was calculated using Pearson's statistics and correlation coefficient was 0.67 for reliability was guaranteed.

\section{FINDINGS}

\section{Determination of livelihood strategies pursued by households in Rongo Sub-County.}

This is the first objective of the study that sought to find out the livelihood strategies that residents of Rongo Sub-county engage in.

Primary Livelihood Activities

The respondents were asked to indicate their primary livelihood activities through structured questions and interview Schedules. Table 2 represents livelihood strategies pursued by household heads in Rongo Sub-County.

Table-2

\begin{tabular}{|l|c|c|}
\hline Activity & Frequency & Percentage Response \\
\hline Agriculture & 80 & 43.2 \\
\hline Gold mining & 61 & 33.0 \\
Wage labour & 9 & 4.9 \\
\hline Business & 32 & 17.3 \\
\hline Others & 3 & 1.6 \\
\hline Total & 185 & 100 \\
\hline
\end{tabular}

According to the results from open-ended questions and interviews on household heads, well fare chairmen, treasurers and secretaries; chiefs and ward administrators represented in Table 2, it is evident that, gold mining is a primary economic activity for $1 / 3$ of those living around gold mining sites, that was $33 . .0$ percent while agricultural activities like sugarcane plantation, maize farming, poultry keeping, just to mention a few, form the major economic activity in these areas. Other very important activities which need not to be neglected as they are also carried out in these areas are small scale businesses and wage labor this supports the work of Funoh [28] who found out that people living around gold mines are also engaged in other activities other than gold mining.

\section{Miners Longevity in Gold Mining}

In order to conclude the livelihood activities pursued by the residents of Rongo Sub-county, miner's longevity in gold mining had to be taken into consideration as shown in Figure 1. 


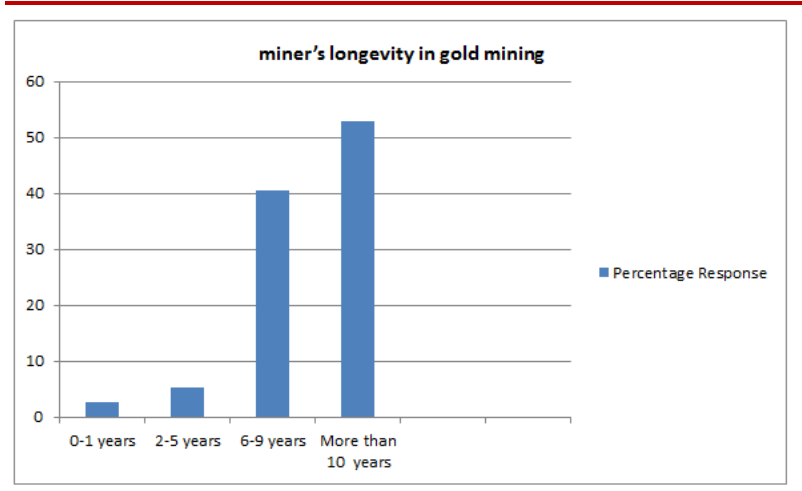

Fig-1: Miners' longevity in gold mining in Rongo Sub-County

The number of gold miners interviewed who had spent more than 10 years in gold mining activities, forms the majority by a percentage that is slightly above average (Figure 1). This is because according to Mitullah et al. [9], gold mining is an old activity in the region and many of them have many years of experience in the sector. Those found with 10 years and above of experience are people who started practicing gold mining elsewhere.

Miners were asked to explain how they joined gold mining activities. Some said, their family members (brothers, sisters, parents and in-laws) initiated them. Others said they joined because the gold mines were in their farms. Other miners joined mining through friends who joined the activity and later on sent news to them to come and try mining. A few others reported that they joined the activity by accident as they searched for fortune.

In conclusion, about $70 \%$ of the miners affirmed that gold mining was their primary activity. The other $30 \%$ carried out gold mining alongside other activities like agriculture which included farming of maize, sweet potatoes, sugarcane, animal husbandry, bee keeping and poultry and wage labor. Some few percentages of residents carry out business as their economic activity.

The results obtained from interview schedules from the chiefs, welfare leaders, and ward administrators indicate that the livelihood strategies practiced in Rongo sub-county include gold mining, sugarcane farming, maize farming, animals husbandry and business. The primary livelihood activity practiced in many households was crop farming. However to many, gold mining is another source of income to some people in the area that has impacted outdoor investment.

\section{CONCLUSION}

Gold mining in the region has created employment opportunities. Those who engage in other activities related to gold mining such as digging, washing and grinding earn their daily bread from there hence a source of income. The findings also indicated that, about $61 \%$ of the miners considered gold mining as their primary activity. The other $39 \%$ either carried out gold mining alongside with other activities like agriculture wage labor and poultry or didn't practice gold mining at all. Some few percentages of residents carry out business as their economic activity. It has confirmed that, gold mining has benefited most of the people in Rongo Sub-county, since most of them, $38.9 \%$, get a monthly income from gold mining between Ksh. 5000-10000, others get Ksh.10000 and above.

\section{RECOMMENDATIONS}

From the findings of this study, it is significant to formulate regulatory measures to ensure that gold mining is practiced within the thresholds of addressing environmental safety, such that pits left are reclaimed to render them productive again. Moreover, policies based on strategies of environmental and resource sustainability for now and posterity should be constituted so that issues of sustainability of gold mining activity initiatives are addressed effectively.

\section{REFERENCE}

1. Perks, R. (2013). Building on the Knowledge Created Under the Communities and Small-Scale Mining. Journal of Artisanal and Small-Scale Mining, 4(2)

2. Peiter, C., Villas, R.C., \& Shinya, W. (2000). Impacts Associated With Small Mining and Quarry Operations. Journal on Natural Resources Forum, 24 (1): 1-9.

3. Bryceson, D. F. (2002). 'Multiplex livelihoods in rural Africa: recasting the terms and conditions of gainful employment', Journal of Modern African Studies, 40(1)1-28.

4. USAID. (2000). Mining for Gold in Siguiri: A Close Look at a High-Risk Population, Report on Guinea, US Agency for International Development, http://www.usai

5. Amankwah, R. K., \& Anim-Sackey, C. (2003). Strategies for Sustainable Development of the Small-Scale Gold and Diamond Mining Industry of Ghana, Resources Policy, 29, (3-4), 131-138,.

6. Vanessa, P., Stewart, L., Rolfe, J. \& Galina, I. (2009). Mining developments and social impacts on communities. Rural Society, 19(3).

7. Collaborative Group on Artisanal and Small-Scale Mining (CASM)

(2003). http://en.wikipedia.org/wiki/Artisanalmini ng_collaborative_group_on_Artisanal_and_small_s cale_mining_28CASM. 2

8. Dreschler, B. (2001). Small-scale Mining and Sustainable Development within the SADC Region, Country Study commissioned by MMSD, 165p. http://www.iied.org/mmsd/

9. Mitullah, W. V., Ogola, J. S., \& Omulo, M. A. (2003). The socioeconomic aspects of Artisanal 
Gold mining in Migori District, Kenya. The socioeconomic impacts of artisanal and small-scale mining in developing countries, 25(1), 260-270.

10. Maxwell, S. (2013). Responsible and Accountable Garment Sector Challenge Fund (RAGS): Working together for a responsible ready-made garment sector- Lessons Learned.

11. Lahiri, D., K. (2007). 'Illegal Coal Mining in Eastern India: Rethinking Legitimacy and Limits of Justice', Economic and Political Weekly, 52(49)814

12. Akabzaa, T., \& Darimani, A. (2001). "Impact of mining sector investment in Ghana: a study of the Tarkwa Mining Region," Drafted Report for SAPRI

13. Otuki, N. (2018). Gold Mining Firm Seeks Approval in Migori Operation. $29^{\text {th }}$ March. Business daily

14. Mathis, A. (2003). Report in Reference to São Chico and Crepurizinho Mining Sites.: Removal of Barriers to Introduction of Cleaner Artisanal Gold Mining and Extraction Technologies. GEF/UNDP/UNIDO.

15. Owusu-Korateng, D. (2008), Mining investment \& community struggles. Review of African Political Economy, 35(117), 467-473.

16. Ocansey, I., T. (2013). Mining Impacts on Agricultural Lands and Food Security. Case study of towns in and around Kyebi in the Eastern Region of Ghana [Bachelor Thesis], Turku University of Applied Sciences, Turku, Finland,

17. Alexander, K.S., Miller, J., \& Lipscombe, N. (2009). Sustainable development in the uplands of Lao PDR, Sustainable Development, 18(4) 62-70.

18. Hinton, J.J., Veiga, M. M. \& Veiga, A.T.C., (2003), Clean Artisanal Gold Mining: A Utopian Approach? Journal of Cleaner Production, 11(2) 99-115

19. Cerutti, P.O, Nasi, R., \& Tacconi, L. (2008). Sustainable Forest Management in Cameroon Needs More than Approved Forest Management
Plans. Ecology and Society 13(2):36.

20. Keita, S. (2001). The Contribution of the Sadiola Gold Mining Project to Poverty Reduction and the Development of Local Mining Communities, Paper presented at MMSD, November 19-20, 2001, London.

21. Maponga, O., \& Ngorima, C. F. (2003). Overcoming environmental problems in the gold panning sector through legislation and education: the Zimbabwean experience. Journal of Cleaner Production, 11(2), 147-157.

22. Maliganya, W., Moyo, S. S., \& Paul R. (2013). Large Scale Mining Activities and the Livelihood of Adjacent Communities in Tanzania: A Case of Geita Gold Mine.

23. KNBS. (2019). The 2019 Kenya Population and Housing Census. Volume 1C Population Distribution by Age, Sex and Administrative Units

24. Enanoria, W. (2005). Introduction to Survey Methodology. Retrieved from http//www.idready.org/courses/2005/spring/surveyi ntroSurveyMethods.pdf September 2018

25. Creswell, W. (2003). Research Design: Qualitative and mixed methods approach. Thousand Oaks. CA Sage.

26. Frankel, J., R., \& Wallen, N., E. (2000). How to Design and Evaluate Research in Education. New York McGraw Hill. Institute of Technology.

27. Kothari, C. R. (2003). Research Methodology: Methods and Techniques ( ${ }^{\text {nd }}$ Ed). New Delhi: New Age International Limited

28. Funoh K. N. (2014). The Impacts of Artisanal Gold Mining on Local Livelihoods and the Environment in the forested areas of Cameroon. Working Paper 150. Bogor, Indonesia: CIFOR

29. Mwango, S. W. (2010). Relationship between corporate governance practices and financial services of teachers' Saccos in Coast province of Kenya (Doctoral dissertation, University of Nairobi, Kenya). 